\title{
Tumor necrosis factor $\alpha$ sensitizes spinal cord TRPV1 receptors to the endogenous agonist $\mathrm{N}$-oleoyldopamine
}

\author{
Diana Spicarova, Jiri Palecek
}

\begin{abstract}
Modulation of synaptic transmission in the spinal cord dorsal horn is thought to be involved in the development and maintenance of different pathological pain states. The proinflamatory cytokine, tumor necrosis factor $\alpha$ (TNF $\alpha$ ), is an established pain modulator in both the peripheral and the central nervous system. Up-regulation of TNF $\alpha$ and its receptors (TNFR) in dorsal root ganglion (DRG) cells and in the spinal cord has been shown to play an important role in neuropathic and inflammatory pain conditions. Transient receptor potential vanilloid 1 (TRPV1) receptors are known as molecular integrators of nociceptive stimuli in the periphery, but their role on the spinal endings of nociceptive DRG neurons is unclear. The endogenous TRPV1 receptor agonist N-oleoyldopamine (OLDA) was shown previously to activate spinal TRPV1 receptors. In our experiments the possible influence of TNF $\alpha$ on presynaptic spinal cord TRPV1 receptor function was investigated. Using the patch-clamp technique, miniature excitatory postsynaptic currents (mEPSCs) were recorded in superficial dorsal horn neurons in acute slices after incubation with $60 \mathrm{nM}$ TNF $\alpha$. A population of dorsal horn neurons with capsaicin sensitive primary afferent input recorded after the TNF $\alpha$ pretreatment had a basal mEPSC frequency of $1.35 \pm 0.20 \mathrm{~Hz}(n=13)$, which was significantly higher when compared to a similar population of neurons in control slices $(0.76 \pm 0.08 \mathrm{~Hz} ; \mathrm{n}=53 ; \mathrm{P}<0.01)$. In control slices application of a low concentration of OLDA ( $0.2 \mathrm{uM}$ ) did not evoke any change in mEPSC frequency. After incubation with TNF $\alpha$, OLDA $(0.2 \mathrm{uM})$ application to slices induced a significant increase in mEPSC frequency $(155.5 \pm 17.5 \% ; P<0.001 ; n=10)$. Our results indicate that TNF $\alpha$ may have a significant impact on nociceptive signaling at the spinal cord level that could be mediated by increased responsiveness of presynaptic TRPV1 receptors to endogenous agonists. This could be of major importance, especially during pathological conditions, when increased levels of TNF $\alpha$ and TNFR are present in the spinal cord.
\end{abstract}

\section{Background}

The cytokine, tumor necrosis factor $\alpha$ (TNF $\alpha$ ), is now well established as a pain modulator in both the peripheral and central nervous systems [1]. There is now mounting evidence of TNF $\alpha$ involvement in inflammatory, neuropathic and cancer-related pain [2]. Several studies have shown a correlation between the level of TNF $\alpha$ expression and the development of allodynia or hyperalgesia [2-5]. Besides increased local TNFa synthesis and release during peripheral inflammation, TNF $\alpha$ up-regulation has also been demonstrated in dorsal root ganglion (DRG) neurons [6-8] and spinal cord $[3,9,10]$

\footnotetext{
* Correspondence: palecek@biomed.cas.cz

Department of Functional Morphology, Institute of Physiology, Academy of Sciences of the Czech Republic, Prague, Czech Republic
}

in experimental models of peripheral neuropathy, including chronic constriction injury (CCI), L5 spinal nerve transection or sciatic nerve crush. It has been suggested that during neuropathy or peripheral inflammation TNF $\alpha$ could be released in the spinal cord mainly from activated glial cells [9-11].

The effect of TNFa is mediated by two receptors: TNFR1 (p55) and TNFR2 (p75). Both receptors have been detected in DRG and spinal cord neurons [12,13]. In different peripheral neuropathy models, TNFR $1 / 2$ receptors are up-regulated in DRG neurons [14-16] and TNFR1 in the spinal cord dorsal horn (DH) [10]. Later studies localized TNFR2 expression exclusively in non-neuronal DRG cells after lipopolysaccharide (LPS) treatment [17] or after inflammation induced by complete Freund's adjuvant (CFA) [18]. It was recently demonstrated that TNFR2 
receptors are crucial for the development of heat hyperalgesia in a cancer-related pain model in mice [4].

Nociceptive DRG neurons express transient receptor potential vanilloid 1 (TRPV1) receptors, which are localized on their peripheral and central endings [19]. In peripheral tissue they serve as molecular integrators of nociceptive stimuli. However, the function of spinal TRPV1 receptors is not fully understood. As temperature increases or $\mathrm{pH}$ decreases, which activate TRPV1 receptors in the periphery, do not occur in the spinal cord, great effort was needed to detect possible endogenous activators of central TRPV1 receptors [20]. Recently, several lipids have been described as potential endogenous agonists of TRPV1 receptors. Most of them also activate cannabinoid receptors, similar to anandamide (AEA, $\mathrm{N}$-arachidonoylethanolamine), which was one of the first substances suggested to act as an endogenous TRPV1 receptor ligand [21]. AEA has been shown to excite cutaneous $C$ nociceptors via TRPV1 receptors activation and to evoke nocifensive behaviour after peripheral application in vivo [22]. Intrathecal AEA administration has been demonstrated to have an analgesic effect, while higher concentrations also evoke pain-related behavior [23]. Other potential endogenous activators of TRPV1 receptors are products of lipoxygenases [24], omega-3 polyunsaturated fatty acids [25] or unsaturated $N$-acyldopamines originally isolated from bovine striatum as $\mathrm{N}$-arachidonoyldopamine (NADA) [26]. Further analysis of striatal extracts resulted in the identification of, among other acyldopamines, $N$-oleoyldopamine (OLDA), which induces thermal hyperalgesia after intraplantar application and possesses a high potency of putative endovanilloid in mobilization of intracellular calcium in TRPV1-transfected cells [27]. Unlike NADA, OLDA is only a weak ligand for rat CB1 receptors; but is recognized by the anandamide membrane transporter while being a poor substrate for fatty-acid amide hydrolase (FAAH) [27]. Behavioral experiments have shown thermal hyperalgesia following intrathecal OLDA administration [28]. Our previous electrophysiological recordings in spinal cord slices demonstrated that application of $10 \mu \mathrm{M}$ OLDA solution increases mEPSC frequency in superficial DH neurons due to specific TRPV1 receptor activation, as demonstrated by TRPV1 antagonists (SB366791, BCTC) application [28]. The concentration of OLDA needed to activate TRPV1 receptors decreased dramatically from $10 \mu \mathrm{M}$ under control conditions to $0.2 \mu \mathrm{M}$ after PKC activation, pretreatment with the inflammatory mediator bradykinin, or in a model of peripheral inflammation [28].

It has been shown previously that TRPV1 receptor expression and sensitivity to capsaicin may be modulated by TNFa pretreatment [4,29-31]. In our experiments we have studied modulation of spinal cord presynaptic TRPV1 receptor function by TNF $\alpha$. We have recorded the frequency of mEPSCs from superficial dorsal horn neurons in spinal cord slices in order to investigate the effect of acute slice incubation with cytokine TNFa on TRPV1 receptor activation by the endogenous agonist, OLDA.

\section{Methods}

Acute spinal cord slices were prepared from male Wistar rats on postnatal days P19 to P23, as was described previously [28]. After anesthesia with pentobarbital sodium $(90 \mathrm{mg} / \mathrm{kg})$, the lumbar spinal cord was removed and immersed in oxygenated ice-cold dissection solution containing (in mM): $95 \mathrm{NaCl}, 1.8 \mathrm{KCl}, 7 \mathrm{MgSO}_{4}$, $0.5 \mathrm{CaCl}_{2}, 1.2 \mathrm{KH}_{2} \mathrm{PO}_{4}, 26 \mathrm{NaHCO}_{3}, 25 \mathrm{D}$-glucose, 50 sucrose. The spinal cord was fixed to a vibratome stage using cyanoacrylate glue (Leica, VT 1000 S, Germany) in a groove between two agar blocks. Acute transverse slices 300 - $350 \mu \mathrm{m}$ thick were cut, incubated in the dissection solution for $30 \mathrm{~min}$ at $33^{\circ} \mathrm{C}$ and then stored in a recording solution at room temperature and allowed to recover for $1 \mathrm{~h}$ before the electrophysiological experiments. Recording solution contained (in $\mathrm{mM}$ ): $127 \mathrm{NaCl}, 1.8 \mathrm{KCl}, 1.2 \mathrm{KH}_{2} \mathrm{PO}_{4}, 2.4 \mathrm{CaCl}_{2}, 1.3 \mathrm{MgSO}_{4}$, $26 \mathrm{NaHCO}_{3}, 25 \mathrm{D}$-glucose. For the actual measurement, slices were transferred into a recording chamber that was perfused continuously with recording solution at a rate $>2 \mathrm{ml} / \mathrm{min}$. All extracellular solutions were saturated with carbogen $\left(95 \% \mathrm{O}_{2}, 5 \% \mathrm{CO}_{2}\right)$ during the whole process.

Patch-clamp recordings were made from individual DH neurons visualized using a differential interference contrast (DIC) microscope (Leica, DM LFSA, Germany) equipped with an infrared-sensitive camera (IR camera Hitachi KP-200P, Japan) with a standard TV/video monitor (Hitachi VM-172, Japan). Patch pipettes were pulled from borosilicate glass tubing (Rückl Glass, Otvovice, Czech Republic). When filled with intracellular solution, they had resistances of 3.5 - 7.0 $\mathrm{M} \Omega$. The intracellular pipette solution contained (in $\mathrm{mM}$ ): 125 gluconic acid lactone, $15 \mathrm{CsCl}, 10$ EGTA, 10 HEPES, $1 \mathrm{CaCl}_{2}, 2 \mathrm{Na}_{2} \mathrm{ATP}, 0.5 \mathrm{NaGTP}$ and was adjusted to $\mathrm{pH}$ 7.2 with $\mathrm{CsOH}$. Voltage-clamp recordings in the wholecell configuration were performed with an AxoPatch $1 \mathrm{D}$ amplifier (Molecular Devices, USA) at room temperature $\left(21^{\circ} \mathrm{C}-24^{\circ} \mathrm{C}\right)$. Whole-cell responses were lowpass filtered at $2 \mathrm{kHz}$ and digitally sampled at $10 \mathrm{kHz}$. The series resistance of neurons was routinely compensated by $80 \%$ and was monitored during the whole experiment. AMPA receptor-mediated MEPSCs were recorded from superficial DH neurons in laminae I and II, clamped at $-70 \mathrm{mV}$ in the presence of $10 \mu \mathrm{M}$ bicuculline, $5 \mu \mathrm{M}$ strychnine and $0.5 \mu \mathrm{M}$ tetrodotoxin 
(TTX). The software package pCLAMP version 9.0 (Axon Instruments, Inc., Foster City, CA, USA) was used for data acquisition and subsequent off-line analysis. Neurons with capsaicin-sensitive primary afferent input were identified by the increase of mEPSC frequency $(>20 \%)$ following capsaicin $(0.2 \mu \mathrm{M})$ administration at the end of the experimental protocol.

All drugs used in this study were of analytical grade and purchased from Sigma-Aldrich (Prague, Czech Republic) or Tocris Bioscience (Bristol, UK). TNFa was dissolved in 0.1\% BSA; capsaicin and OLDA were dissolved in dimethylsulfoxide (DMSO), which had a concentration $<0.1 \%$ in the final solution.

Data segments of 2 min duration were analyzed for each experimental condition. Only mEPSCs with an amplitude of $5 \mathrm{pA}$ or greater (which corresponded to at least twice the noise level) were included in the frequency analysis. In the case of amplitude analysis, the same events and data segments were used. Data are expressed as means \pm standard error of the mean (SEM). Some data were normalized as a percentage of the control values (100\%). One-way ANOVA and oneway ANOVA repeated measures followed by post hoc test (Bonferroni) were used for statistical comparisons and $\mathrm{P}<0.05$ was considered to be statistically significant. A Kolmogorov-Smirnov test was used to evaluate statistical significance for cumulative data.

All experiments were approved by the local Institutional Animal Care and Use Committee and were consistent with the guidelines of the International Association for the Study of Pain, the National Institutes of Health Guide for the Care and Use of Laboratory Animals and the European Communities Council Directive of 24 November 1986 (86/609/EEC).

\section{Results}

Spinal cord slices were incubated in $60 \mathrm{nM}$ TNF $\alpha$ for at least $2 \mathrm{~h}$ before the actual experiments. Recordings from 16 neurons in slices incubated with TNF $\alpha$ were made altogether. The application of the endogenous TRPV1 receptor agonist OLDA $(0.2 \mu \mathrm{M})$ increased $\mathrm{mEPSC}$ frequency in 10 of the $16 \mathrm{DH}$ neurons tested. At the end of each recording, $0.2 \mu \mathrm{M}$ capsaicin was administered to confirm input from nociceptive primary afferents expressing TRPV1 receptors. Capsaicin is known to increase $\mathrm{mEPSC}$ frequency in superficial DH neurons in a concentration-dependent manner via presynaptic TRPV1 receptors localized on central terminals of DRG neurons $[28,32]$. Capsaicin application in our experiments increased mEPSC frequency in 13 of the $16 \mathrm{DH}$ neurons by $372.6 \pm 78.1 \%$. All 10 neurons that responded to the OLDA application were also responsive to the capsaicin application (10 out of 13).

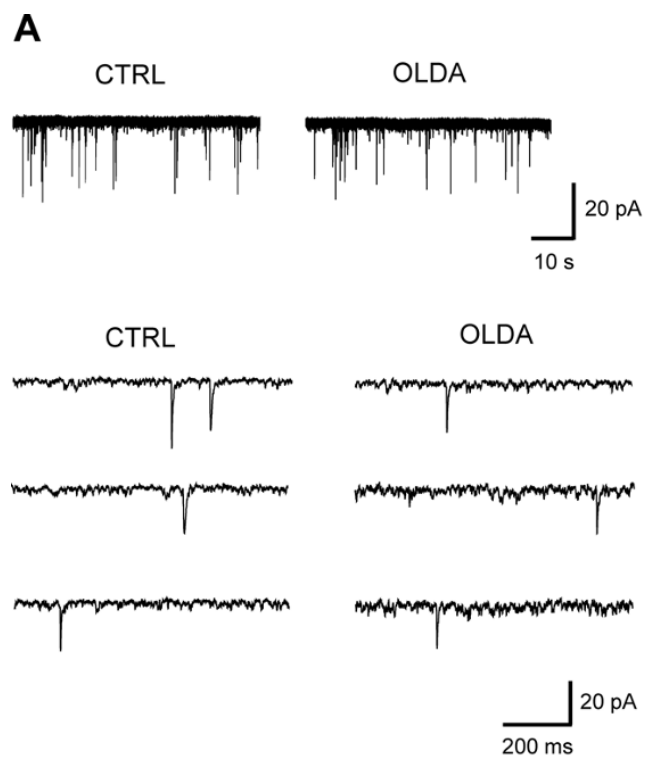

B
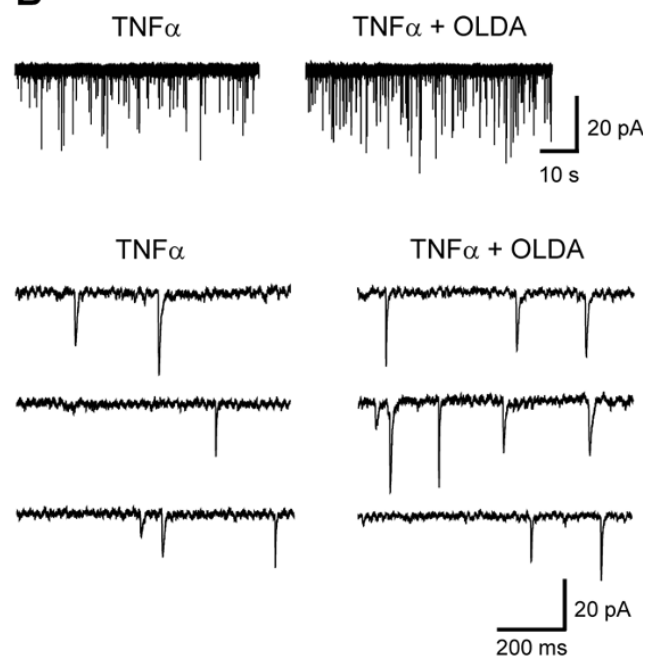

C

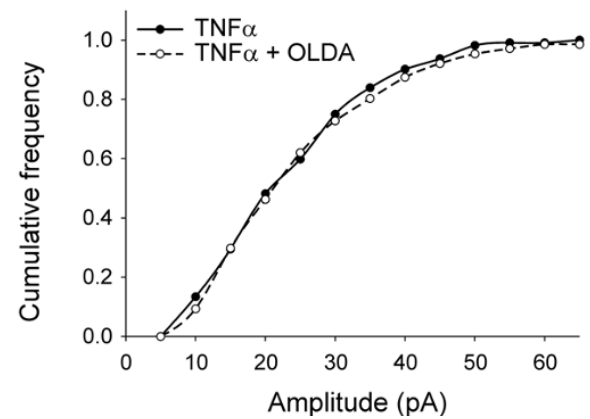

Figure 1 Application of a low concentration of OLDA $(0.2 \mu \mathrm{M})$ did not change $m E P S C$ frequency in a superficial dorsal horn neuron, as recorded under control conditions $(A)$, while a significant increase in mEPSC frequency was observed in slices incubated with the cytokine TNF $\alpha(60 \mathrm{nM} ; \mathrm{B})$. The amplitude of the mEPSCs was not changed after OLDA application in this neuron (C). 


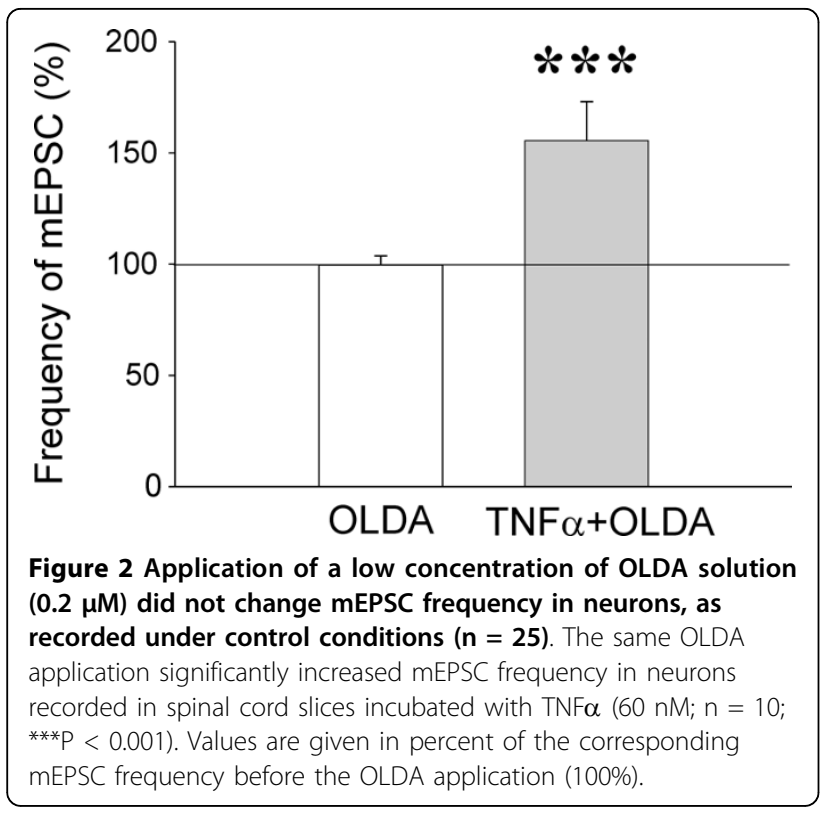

We have shown previously that application of a low concentration of OLDA $(0.2 \mu \mathrm{M})$ does not evoke any changes under control conditions [28]. Basal mEPSC frequency in the control recordings established as $100 \%$ did not change during OLDA $(0.2 \mu \mathrm{M})$ application $(99.6 \pm 4.0 \% ; n=25$; Figs. $1 \mathrm{~A}$ and 2$)$. In the actual measurements, the low concentration of OLDA solution $(0.2 \mu \mathrm{M})$ applied under the same experimental conditions increased the mEPSC frequency to $155.5 \pm 17.5 \%$ $(\mathrm{P}<0.001 ; \mathrm{n}=10)$ in acute spinal cord slices incubated with TNF $\alpha$, when compared to the control values before the OLDA application (Figs. 1B and 2). Capsaicin application in this population of neurons increased mEPSC frequency to a higher level $(387.4 \pm 109.5 \%$; $n=10)$ than did the endogenous agonist. Increase in the absolute mEPSC frequency during OLDA application in neurons incubated with TNFa $(1.78 \pm 0.22 \mathrm{~Hz})$ was also statistically significantly different from the control mEPSC frequency before OLDA application $(1.21 \pm 0.17$ $\mathrm{Hz} ; \mathrm{P}<0.01$; Fig. 3) and from the basal mEPSC frequency recorded in control slices without the TNF $\alpha$ pretreatment $(0.76 \pm 0.13 \mathrm{~Hz} ; \mathrm{n}=25 ; \mathrm{P}<0.001)$. The basal mEPSC frequency $(1.21 \pm 0.17 \mathrm{~Hz})$ recorded in neurons in TNFa incubated slices was significantly higher $(\mathrm{P}<0.05)$ when compared to the basal mEPSC frequency $(0.76 \pm 0.13 \mathrm{~Hz})$ recorded from neurons in control slices (Fig. 3).

Incubation of spinal cord slices with TNF $\alpha$ did not change the average mEPSC amplitude in the recorded neurons during OLDA $(23.02 \pm 2.98 \mathrm{pA} ; \mathrm{n}=10)$ application compared to control values before its application $(21.98 \pm 2.50 \mathrm{pA})$ and compared to mEPSC amplitude in neurons from control slices $(24.12 \pm 1.23 \mathrm{pA}$;

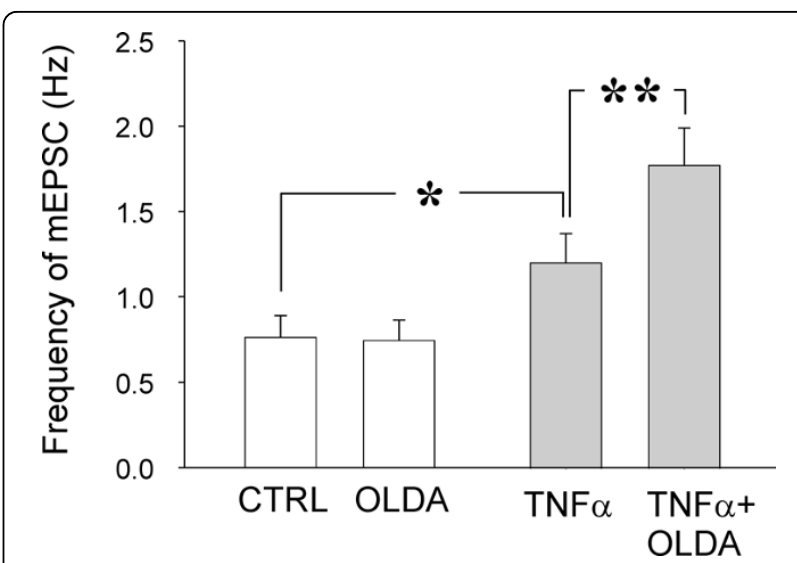

Figure 3 In control slices without TNF $\alpha$ pretreatment, OLDA application did not induce a significant change in mEPSC frequency. Incubation with the cytokine TNF $\alpha$ increased basal mEPSC frequency $\left(n=10\right.$; ${ }^{*} \mathrm{P}<0.05$ ) in a population of $\mathrm{DH}$ neurons with capsaicin-sensitive primary afferent fibre inputs, when compared to recordings from control slices without TNF $\alpha$ incubation ( $n=25$ ). The high statistical significance of the mEPSC frequency increase during OLDA application in neurons after TNF $\alpha$ incubation was also evident without data normalization ( ${ }^{* *} \mathrm{P}<0.01$ ).

$\mathrm{n}=25)$. This is documented also by a cumulative amplitude distribution (Fig. 1C).

All recorded superficial DH neurons with input from TRPV1 receptors containing primary nociceptive fibres incubated with TNF $\alpha$ had a significantly higher basal frequency of mEPSCs $(1.35 \pm 0.20 \mathrm{~Hz} ; \mathrm{n}=13 ; \mathrm{P}<0.01)$ compared to the same population of control neurons $(0.76 \pm 0.08 \mathrm{~Hz} ; \mathrm{n}=53)$ [28]. In contrast, neurons without input from primary afferents containing TRPV1 receptors and incubated with TNF $\alpha$ had a lower basal mEPSC frequency $(1.02 \pm 0.56 \mathrm{~Hz} ; \mathrm{n}=3)$ compared to the same population of neurons in control slices $(2.07 \pm$ $0.39 \mathrm{~Hz} ; \mathrm{n}=23$; $\mathrm{P}>0.05)$. Average basal mEPSC frequency of all of the recorded neurons was not different between the neurons recorded in slices incubated with TNF $\alpha(1.28 \pm 0.18 ; \mathrm{n}=16)$ and in control slices $(1.13 \pm$ $0.14 ; \mathrm{n}=76)$. While the number of recorded neurons without presynaptic input from capsaicin sensitive fibres was very low $(n=3)$, we cannot deduce from our results if there was any significant effect of TNFa on the $\mathrm{mEPSC}$ frequency in this population of neurons. There was no change in average mEPSC amplitude in DH neurons with input from capsaicin sensitive and insensitive primary afferent fibres incubated with TNF $\alpha$ compared to the appropriate populations of neurons in control slices without TNF $\alpha$ incubation.

\section{Discussion}

Application of a low concentration $(0.2 \mu \mathrm{M})$ of the TRPV1 endogenous agonist OLDA does not evoke any changes in mEPSC frequency recorded from superficial 
dorsal horn neurons under control conditions without TNF $\alpha$ incubation [28]. In the present experiments we have demonstrated that TNF $\alpha$ pretreatment significantly increases sensitivity to OLDA application in $10(\sim 60 \%)$ out of the total of 16 recorded neurons. Our hypothesis assumes that this effect is mediated by TNFR-induced modulation of TRPV1 receptors. It thus seems plausible to suggest that both TRPV1 and TNFR receptors have to be expressed in the presynaptic endings for this effect to be present. Out of the 16 neurons, 3 did not respond to the capsaicin application, implying a lack of TRPV1 receptors in these neurons. In the population of 13 neurons responding with increased mEPSC frequency to the capsaicin application, 3 neurons did not respond to the OLDA application, possibly due to an absence of TNFR receptors, while 10 out of the 13 neurons ( 77\%) responded to the OLDA application.

The importance of TNFR1 receptors for development of neuropathic pain syndromes appears to be well documented. TNFR1 receptors are not only present on DRG neuronal bodies but also at numerous central branches of DRG neurons in the spinal cord dorsal horn [33]. A crucial role of TNFR1 receptor activation in the experimental model of neuropathic pain using chronic constriction injury of the sciatic nerve has been demonstrated using neutralizing antibodies to the TNFR1 receptor to reduce thermal hyperalgesia and mechanical allodynia [34]. Ventral root transection accompanied with mechanical allodynia and thermal hyperalgesia increases immunoreactivity of TNF $\alpha$ and TNFR1 receptors in ipsilateral DRG and bilaterally in the spinal cord DH [35]. A role for TNFR2 receptors in heat hyperalgesia has been implicated in a model of cancer pain where TRPV1 protein up-regulation in DRG neurons is attenuated in TNFR2 knock-out mice [4].

Coexpression of mRNA for TNFR1 and TRPV1 receptors [17] and colocalization of TNFR1 and TRPV1 immunoreactivity [29] in DRG neurons has been reported. Long-term application of TNF $\alpha(48 \mathrm{~h})$ increases the number of TRPV1 immunopositive DRG neurons in culture. This increased expression of TRPV1 receptors is dependent on ERK (extracellular regulated kinase $=\mathrm{p} 44 / \mathrm{p} 42$ MAP kinase) activation and TNFR1 receptors, as has been shown using DRG neurons isolated from TNFR1 ${ }^{-1-}$ knock out mice [29]. In contrast, TRPV1 receptor up-regulation in DRG neurons is dependent on TNFR2 receptors in tumor-bearing mice [4]. The increase of TRPV1 protein level after TNF $\alpha$ application correlates well with a previous demonstration of an increased number of DRG neurons labeled with cobalt staining after TRPV1 receptor activation by capsaicin in neurons cultivated with TNFa [31]. The increased cobalt staining in these experiments is dependent on the activation of cyclooxygenase, in contrast to other findings [29]. The change in capsaicin sensitivity after TNF $\alpha$ treatment is rapid, with an increase after $4 \mathrm{~h}$ of incubation [31]. TNF $\alpha$ stimulation of cultured DRG neurons produces an increase in TRPV1 receptor protein level after 1 and $2 \mathrm{~h}$ of incubation [4]. In trigeminal neurons, TNF $\alpha$ application increases CGRP release after capsaicin stimulation [30]. In these experiments, doubling of TRPV1 receptor mRNA was evident only after 30 min of TNF $\alpha$ incubation.

In our experiments the cell bodies of DRG neurons were absent during the TNF $\alpha$ incubation of spinal cord slices. The increased sensitivity to OLDA application was thus most likely mediated through TRPV1 receptors phosphorylation and/or their translocation from the cytoplasm to the presynaptic ending membrane. Increased sensitivity of TRPV1 receptors to agonists due to PKC- or PKA-mediated phosphorylation has been repeatedly demonstrated [36]. Also, TNF $\alpha$ incubation ( $5 \mathrm{~min}$ ) has been shown to have a fast potentiating effect on capsaicin-stimulated increases in intracellular accumulation of $\mathrm{Ca}^{2+}$ ions [30]. Capsaicin-evoked currents are robustly potentiated after only $60 \mathrm{~s}$ of TNF $\alpha$ application in cultured DRG neurons, and this effect is mediated via activation of PKC or p38/MAP kinase [4]. It is thus probable that the effect of TNF $\alpha$ on TRPV1 receptors is mediated by similar pathways in our experiments, while transcriptional changes may also play an important role under pathological conditions in vivo, where spinal TNF $\alpha$ has been shown to play an important role [37].

In our experiments we did not record any significant change in the mEPSC amplitude, which is in good agreement with previous findings [38,39]. However, postsynaptic changes due to TNF $\alpha$ incubation could have most likely also occurred. Regulation of NMDA receptor activity or AMPA receptor expression by TNF $\alpha$ has been described for other areas of the CNS [40]. Neutralization of TNF $\alpha$ in the rostral ventromedial medulla (RVM), a major component of brainstem descending pain modulatory circuitry, attenuates phosphorylation of NMDA receptor NR1 subunits [41]. TNF $\alpha$ induces enhancement of synaptic efficacy by increasing surface AMPA receptor expression in hippocampal neurons [42]. It has also been documented that TNFa enhances spontaneous EPSCs and potentiates AMPAand NMDA-mediated currents due to up-regulation of spinal chemokine MCP-1 and activation of its postsynaptic CCR2 receptors in DH neurons [43]. Acute TNF $\alpha$ application in spinal cord slices increases the frequency of spontaneous EPSCs in some lamina II neurons (8 of 14 neurons), and also increases AMPA- (5 of 9 neurons) and NMDA- (all recorded neurons) stimulated currents [38]. Increase of sEPSC and mEPSC frequencies during acute application of TNF $\alpha$ has been 
confirmed by Youn et al. (2008) [39], together with the observation of a TNF $\alpha$-stimulated increase in spontaneous IPSC frequency. From previously published results and our study, it is evident that TNF $\alpha$ - induced modulation of excitatory synaptic transmission in the spinal cord dorsal horn is a complex process mediated by fast mechanisms and by slow transcription-dependent changes.

Our results suggest that increased levels of TNFa and its receptors under pathological conditions may have considerable impact on the function of spinal cord TRPV1 receptors. The resulting increased sensitivity of TRPV1 receptors to endogenous agonist may significantly modulate nociceptive synaptic transmission in the spinal cord dorsal horn. While additional experiments are needed to elucidate the specific mechanisms involved in TNF $\alpha$-induced modulation of TRPV1 receptor function, it is clear that these results may also point to new targets for pain therapy.

\section{Acknowledgements}

This work was supported by GACR 305/09/1228, MSMT LC554, AV0Z 50110509.

\section{Authors' contributions}

JP conceived and designed the study, DS performed and analyzed the experiments. DS and JP drafted the manuscript. Both authors have read and approved the final version of the manuscript.

\section{Competing interests}

The authors declare that they have no competing interests.

Received: 28 June 2010 Accepted: 26 August 2010

Published: 26 August 2010

\section{References}

1. McMahon SB, Cafferty WB, Marchand F: Immune and glial cell factors as pain mediators and modulators. Exp Neurol 2005, 192:444-462.

2. Marchand F, Perretti M, McMahon SB: Role of the immune system in chronic pain. Nat Rev Neurosci 2005, 6:521-532.

3. DeLeo JA, Colburn RW, Rickman AJ: Cytokine and growth factor immunohistochemical spinal profiles in two animal models of mononeuropathy. Brain Res 1997, 759:50-57.

4. Constantin CE, Mair N, Sailer CA, Andratsch M, Xu ZZ, Blumer MJ, Scherbakov N, Davis JB, Bluethmann H, Ji RR, Kress M: Endogenous tumor necrosis factor alpha (TNFalpha) requires TNF receptor type 2 to generate heat hyperalgesia in a mouse cancer model. J Neurosci 2008, 28:5072-5081.

5. Sommer C, Schafers M: Painful mononeuropathy in C57BL/WId mice with delayed wallerian degeneration: differential effects of cytokine production and nerve regeneration on thermal and mechanical hypersensitivity. Brain Res 1998, 784:154-162.

6. Schafers M, Geis C, Brors D, Yaksh TL, Sommer C: Anterograde transport of tumor necrosis factor-alpha in the intact and injured rat sciatic nerve. $J$ Neurosci 2002, 22:536-545.

7. Schafers M, Geis C, Svensson Cl, Luo ZD, Sommer C: Selective increase of tumour necrosis factor-alpha in injured and spared myelinated primary afferents after chronic constrictive injury of rat sciatic nerve. Eur J Neurosci 2003, 17:791-804.

8. Jancalek R, Dubovy P, Svizenska I, Klusakova I: Bilateral changes of TNFalpha and IL-10 protein in the lumbar and cervical dorsal root ganglia following a unilateral chronic constriction injury of the sciatic nerve. $J$ Neuroinflammation 2010, 7:11.
9. Winkelstein BA, Rutkowski MD, Sweitzer SM, Pahl JL, DeLeo JA: Nerve injury proximal or distal to the DRG induces similar spinal glial activation and selective cytokine expression but differential behavioral responses to pharmacologic treatment. J Comp Neurol 2001, 439:127-139.

10. Ohtori S, Takahashi K, Moriya H, Myers RR: TNF-alpha and TNF-alpha receptor type 1 upregulation in glia and neurons after peripheral nerve injury: studies in murine DRG and spinal cord. Spine (Phila Pa 1976) 2004, 29:1082-1088.

11. Raghavendra V, Tanga FY, DeLeo JA: Complete Freunds adjuvant-induced peripheral inflammation evokes glial activation and proinflammatory cytokine expression in the CNS. Eur J Neurosci 2004, 20:467-473.

12. Pollock J, McFarlane SM, Connell MC, Zehavi U, Vandenabeele P, MacEwan DJ, Scott RH: TNF-alpha receptors simultaneously activate $\mathrm{Ca}^{2+}$ mobilisation and stress kinases in cultured sensory neurones. Neuropharmacology 2002, 42:93-106.

13. Yan P, Liu N, Kim GM, Xu J, Xu J, Li Q, Hsu CY, Xu XM: Expression of the type 1 and type 2 receptors for tumor necrosis factor after traumatic spinal cord injury in adult rats. Exp Neurol 2003, 183:286-297.

14. Dubovy P, Jancalek R, Klusakova I, Svizenska I, Pejchalova K: Intra- and extraneuronal changes of immunofluorescence staining for TNF-alpha and TNFR1 in the dorsal root ganglia of rat peripheral neuropathic pain models. Cell Mol Neurobiol 2006, 26:1205-1217.

15. Shubayev VI, Myers RR: Axonal transport of TNF-alpha in painful neuropathy: distribution of ligand tracer and TNF receptors. $J$ Neuroimmunol 2001, 114:48-56.

16. Schafers M, Sorkin LS, Geis C, Shubayev VI: Spinal nerve ligation induces transient upregulation of tumor necrosis factor receptors 1 and 2 in injured and adjacent uninjured dorsal root ganglia in the rat. Neurosci Lett 2003, 347:179-182.

17. Li Y, Ji A, Weihe E, Schafer MK: Cell-specific expression and lipopolysaccharide-induced regulation of tumor necrosis factor alpha (TNFalpha) and TNF receptors in rat dorsal root ganglion. $J$ Neurosci 2004, 24:9623-9631.

18. Inglis JJ, Nissim A, Lees DM, Hunt SP, Chernajovsky Y, Kidd BL: The differential contribution of tumour necrosis factor to thermal and mechanical hyperalgesia during chronic inflammation. Arthritis Res Ther 2005, 7:R807-816.

19. Guo A, Vulchanova L, Wang J, Li X, Elde R: Immunocytochemical localization of the vanilloid receptor 1 (VR1): relationship to neuropeptides, the P2X3 purinoceptor and IB4 binding sites. Eur J Neurosci 1999, 11:946-958.

20. Spicarova D, Palecek J: The role of spinal cord vanilloid (TRPV1) receptors in pain modulation. Physiol Res 2008, 57(Suppl 3):569-77.

21. Zygmunt PM, Petersson J, Andersson DA, Chuang H, Sorgard M, Di Marzo V, Julius D, Hogestatt ED: Vanilloid receptors on sensory nerves mediate the vasodilator action of anandamide. Nature 1999, 400:452-457.

22. Potenzieri C, Brink TS, Simone DA: Excitation of cutaneous $C$ nociceptors by intraplantar administration of anandamide. Brain Res 2009, 1268:38-47.

23. Horvath $G$, Kekesi $G$, Nagy E, Benedek $G$ : The role of TRPV1 receptors in the antinociceptive effect of anandamide at spinal level. Pain 2008, 134:277-284

24. Hwang SW, Cho H, Kwak J, Lee SY, Kang CJ, Jung J, Cho S, Min KH, Suh YG, Kim D, Oh U: Direct activation of capsaicin receptors by products of lipoxygenases: endogenous capsaicin-like substances. Proc Natl Acad SC USA 2000, 97:6155-6160.

25. Matta JA, Miyares RL, Ahern GP: TRPV1 is a novel target for omega-3 polyunsaturated fatty acids. J Physiol 2007, 578:397-411.

26. Huang SM, Bisogno T, Trevisani M, Al-Hayani A, De Petrocellis L, Fezza F, Tognetto M, Petros TJ, Krey JF, Chu CJ, et al: An endogenous capsaicin-like substance with high potency at recombinant and native vanilloid VR1 receptors. Proc Natl Acad Sci USA 2002, 99:8400-8405.

27. Chu CJ, Huang SM, De Petrocellis L, Bisogno T, Ewing SA, Miller JD, Zipkin RE, Daddario N, Appendino G, Di Marzo V, Walker JM: Noleoyldopamine, a novel endogenous capsaicin-like lipid that produces hyperalgesia. J Biol Chem 2003, 278:13633-13639.

28. Spicarova D, Palecek J: The role of the TRPV1 endogenous agonist $\mathrm{N}$ Oleoyldopamine in modulation of nociceptive signaling at the spinal cord level. J Neurophysiol 2009, 102:234-243.

29. Hensellek S, Brell P, Schaible HG, Brauer R, Segond von Banchet G: The cytokine TNFalpha increases the proportion of DRG neurones expressing 
the TRPV1 receptor via the TNFR1 receptor and ERK activation. Mol Cell Neurosci 2007, 36:381-391.

30. Khan AA, Diogenes A, Jeske NA, Henry MA, Akopian A, Hargreaves KM: Tumor necrosis factor alpha enhances the sensitivity of rat trigeminal neurons to capsaicin. Neuroscience 2008, 155:503-509.

31. Nicol GD, Lopshire JC, Pafford CM: Tumor necrosis factor enhances the capsaicin sensitivity of rat sensory neurons. J Neurosci 1997, 17:975-982.

32. Baccei ML, Bardoni R, Fitzgerald M: Development of nociceptive synaptic inputs to the neonatal rat dorsal horn: glutamate release by capsaicin and menthol. J Physiol 2003, 549:231-242.

33. Holmes GM, Hebert SL, Rogers RC, Hermann GE: Immunocytochemical localization of TNF type 1 and type 2 receptors in the rat spinal cord. Brain Res 2004, 1025:210-219.

34. Sommer C, Schmidt C, George A: Hyperalgesia in experimental neuropathy is dependent on the TNF receptor 1. Exp Neurol 1998, 151:138-142.

35. Xu JT, Xin WJ, Zang Y, Wu CY, Liu XG: The role of tumor necrosis factoralpha in the neuropathic pain induced by Lumbar 5 ventral root transection in rat. Pain 2006, 123:306-321.

36. Pingle SC, Matta JA, Ahern GP: Capsaicin receptor: TRPV1 a promiscuous TRP channel. Handb Exp Pharmacol 2007, 155-171.

37. Boettger MK, Weber K, Grossmann D, Gajda M, Bauer R, Bar KJ, Schulz S, Voss A, Geis C, Brauer R, Schaible HG: Spinal tumor necrosis factor alpha neutralization reduces peripheral inflammation and hyperalgesia and suppresses autonomic responses in experimental arthritis: a role for spinal tumor necrosis factor alpha during induction and maintenance of peripheral inflammation. Arthritis Rheum 2010, 62:1308-1318.

38. Kawasaki Y, Zhang L, Cheng JK, Ji RR: Cytokine mechanisms of central sensitization: distinct and overlapping role of interleukin-1 beta, interleukin-6, and tumor necrosis factor-alpha in regulating synaptic and neuronal activity in the superficial spinal cord. J Neurosci 2008, 28:5189-5194.

39. Youn DH, Wang H, Jeong SJ: Exogenous tumor necrosis factor-alpha rapidly alters synaptic and sensory transmission in the adult rat spinal cord dorsal horn. J Neurosci Res 2008, 86:2867-2875.

40. Leung L, Cahill CM: TNF-alpha and neuropathic pain-a review. Neuroinflammation 2010, 7:27.

41. Wei F, Guo W, Zou S, Ren K, Dubner R: Supraspinal glial-neuronal interactions contribute to descending pain facilitation. J Neurosci 2008, 28:10482-10495.

42. Beattie EC, Stellwagen D, Morishita W, Bresnahan JC, Ha BK, Von Zastrow M, Beattie MS, Malenka RC: Control of synaptic strength by glial TNFalpha. Science 2002, 295:2282-2285.

43. Gao YJ, Zhang L, Samad OA, Suter MR, Yasuhiko K, Xu ZZ, Park JY, Lind AL, Ma Q, Ji RR: JNK-induced MCP-1 production in spinal cord astrocytes contributes to central sensitization and neuropathic pain. J Neurosci 2009, 29:4096-4108.

doi:10.1186/1742-2094-7-49

Cite this article as: Spicarova and Palecek: Tumor necrosis factor $\alpha$ sensitizes spinal cord TRPV1 receptors to the endogenous agonist $\mathrm{N}$ oleoyldopamine. Journal of Neuroinflammation 2010 7:49.

\section{Submit your next manuscript to BioMed Central and take full advantage of:}

- Convenient online submission

- Thorough peer review

- No space constraints or color figure charges

- Immediate publication on acceptance

- Inclusion in PubMed, CAS, Scopus and Google Scholar

- Research which is freely available for redistribution

Submit your manuscript at www.biomedcentral.com/submit
Biomed Central 